\title{
Don't Throw Caution to the Wind: In the green energy transition, not all critical minerals will be goldmines
}

\section{MAY 2020}

Perrine Toledano, Martin Dietrich Brauch,

Solina Kennedy, and Howard Mann

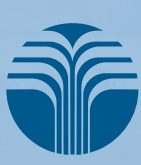

Columbia Center on Sustainable Investment A JOINT CENTER OF COLUMBIA LAW SCHOOL AND THE EARTH INSTITUTE, COLUMBIA UNIVERSITY

\section{Key Messages}

- The green energy transition will be mineral intensive. Manufacturing wind turbines, solar panels, geothermal heat pumps, and batteries is set to significantly increase demand for so-called "critical" minerals.

- Forecasts of increased demand for critical minerals-including as a result of post-COVID-19 stimulus plans-prompt high expectations in mineral-rich countries and suggest promising opportunities for developing countries.

- However, projects to increase the primary extraction of critical minerals rest on bullish forecasts and uncertain terrain, because of factors including ever-adapting technology leading to increased mineral performance; substitutions due to high mineral prices or supply scares; reduced primary extraction due to increased recycling, reuse, and the circular economy; and greater reliance on agromining and biomining.

- Investments in the primary extraction of critical minerals could become obsolete and economically stranded. Over-investing in production may outstrip demand and lead to minimal benefits for many countries.

- Governments, international actors, and mining advocates seeking to optimize the value of green energy mineral reserves should heed caution when pursuing and promoting the mining of critical minerals. We provide specific recommendations starting on page 7 .

\section{Introduction}

The green energy transition will be exceedingly mineral intensive. ${ }^{1}$ Scaling up the manufacturing of wind turbines, solar panels, geothermal heat pumps, and batteries to power cleaner technologies is set to generate an exponential increase in the demand ${ }^{2}$ for so-called "critical" minerals and metals. ${ }^{3}$

Expectations for global economic recovery from the COVID-19 pandemic may also be boosting hopes of increased mineral demand, in particular as the promotion of green energy ${ }^{4}$ might be part of post-pandemic stimulus plans ${ }^{5}$ for certain countries.

While seeking to optimize the value of green energy mineral reserves, governments-as well as international actors and mining advocates-should heed caution when pursuing and promoting the mining of critical minerals. These projected development opportunities rest on bullish forecasts and uncertain terrain. Caution is therefore necessary to avoid creating expectations that in many cases will not be met, or over-investing in production that may outstrip demand and lead to minimal benefits for many countries.

1 Arrobas, Daniele La Porta, et al. "The Growing Role of Minerals and Metals for a Low Carbon Future" The World Bank. June 30, 2017 http://documents.worldbank.org/curated/en/207371500386458722/ The-Growing-Role-of-Minerals-and-Metals-for-a-Low-Carbon-Future 2 "Climate-Smart Mining: Minerals for Climate Action". World Bank. http:// pubdocs.worldbank.org/en/961711588875536384/Minerals-for-Climate-ActionThe-Mineral-Intensity-of-the-Clean-Energy-Transition.pdf;

"A Green Transition or an Expansion of Extraction?". World Rainforest

Movement. https://wrm.org.uy/articles-from-the-wrm-bulletin/

viewpoint/a-green-transition-or-an-expansion-of-extraction

3 Henceforth, "minerals and metals" will be together referred to as "minerals."

4 Calma, Justine. "Clean Energy Could Get Americans

Back to Work Post-Pandemic". The Verge. April 30,

2020. https://www.theverge.com/2020/4/30/21243011/

clean-energy-renewables-coronavirus-recession-stimulus-unemployment

5 Green Stimulus Proposal. "A Green Stimulus to Rebuild

Our Economy". Medium. May 5, 2020. https://medium.com/@

green_stimulus_now/a-green-stimulus-to-rebuild-our-economy-1e7030a1d9ee 
The need for a sense of caution is evidenced by two World Bank reports on climate-smart mining. The first report, published on May 11, 2020, highlights not only the expected growth but also the volatility in expectations. ${ }^{6}$ In this report, the World Bank estimates that the clean energy transition could lead the production of minerals such as cobalt, graphite, and lithium to increase by up to $500 \%$ by 2050 .

But the publication differs from an earlier 2017 World Bank report $^{7}$ that, using a similar methodology, had presented even higher estimates, projecting a $965 \%$ increase in the global demand of lithium by 2050 , and a six-fold increase in cobalt during the same period. The primary explanation for this difference is how the World Bank factored recycling and reuse into the estimated numbers in 2020, which it had not done in 2017; and signals the importance of understanding how estimates for use of materials might not translate into extracting new materials. This distinction is part of what we explore below.

\section{Anticipated demand for minerals is fueling great expectations in resource-rich countries}

The forecasts for growth in green energy minerals suggest promising opportunities for developing countries ${ }^{8}$ and prompt high expectations in mineral-rich countries-some of which have already begun taking action. For example:

- The Democratic Republic of Congo, the world's number one producer of cobalt, nearly tripled the royalty rate ${ }^{9}$ to be paid by cobalt miners in 2018 from $3.5 \%$ to $10 \%$ after declaring the mineral a "strategic" substance.

- Western Australia, in March 2020, changed the lithium royalty regime to encourage beneficiation into lithium hydroxide and lithium carbonate. ${ }^{10}$

- In Chile-home to roughly $11 \%$ of the world's lithium resources ${ }^{11}$ and the number one exporter of coppermajor investment and policy action has been taken

\footnotetext{
Kirsten Hund et al., "The Mineral Intensity of the Clean Energy

Transition". The World Bank, May 11, 2020. http://pubdocs.worldbank.org/ en/961711588875536384/Minerals-for-Climate-Action-The-Mineral-Intensity-ofthe-Clean-Energy-Transition.pdf

7 Arrobas, Daniele La Porta, et al. "The Growing Role of Minerals and Metals for a Low Carbon Future". The World Bank. June 30, 2017

8 Ayuk, E. T. et al. "Mineral Resource Governance in the 21st Century: Gearing extractive industries towards sustainable development "The International Resource Panel United Nations Environment Programme, Nairobi, Kenya. 2020.

9 "Congo Declares Cobalt 'Strategic', Nearly Tripling Royalty

Rate". Reuters. December 3, 2018. https://www.reuters.com/article/ us-congo-cobalt-idUSKBN1O220D

10 Other-Gee, Alex. "New Lithium Royalty Regime Commences in Western Australia - Technical Update - MinterEllison".

MinterEllison. April 6, 2020. http://www.minterellison.com/articles/ new-lithium-royalty-regime-commences-in-western-australia

11 "Mineral Commodity Summaries 2020". U.S. Department of the Interior \& U.S Geological Survey. January 31, 2020. https://pubs.usgs.gov/periodicals/mcs2020/ mcs2020.pd
}

in response to the predicted $85 \%$ increase $^{12}$ in the lithium battery industry in the next 20 years, and expected US\$ 1.8 billion in lithium investments by 2022. ${ }^{13}$ Chile's innovation programme, Corporación Alta Ley, designed a 2035 Technology Roadmap with the objective to reach US\$ 4 billion in annual mining exports. ${ }^{14}$ Additionally, the country's mining ministry and development agency has set up a US\$ 193 million"15 "Technological Institute for solar energy, low emission mining and advanced materials of lithium and other minerals." 16 The mining ministry is working to further build out its local lithium value chain ${ }^{17}$ by setting out provisions to incentivise downstream industries ${ }^{18}$ and clarifying existing policies $^{19}$ to push public and private investment to double Chile's lithium carbonate production to 230,000 metric tons per year by $2023 .{ }^{20}$

- Bolivia has long dreamed of exploiting its sizable lithium deposits, currently estimated to account for more than one-quarter of the world's resources ${ }^{21}$ of the metal. In 2008, the government declared the development of lithium-as well as other resources found in the Uyuni salt flat-a national priority. ${ }^{22}$ The national plan for lithium development has since been led by Bolivian state-owned company Yacimientos de Litio Bolivianos (YLB). To develop national technology and avoid dependency on foreign investment, the Bolivian government earmarked investments of around US\$ 1 billion. ${ }^{23}$ In 2018, YLB formed a joint venture with German company $\mathrm{ACl}$ Systems, which planned to invest

12 "Chile to Boost Lithium Carbonate Production." Chinatungstein.com. January 2, 2020. http://news.chinatungsten.com/en/tungsten-news/126940-tpn-8788

13 "Comisión Chilena Del Cobre (COCHILCO)". BNamericas.com. https://www. bnamericas.com/en/company-profile/comision-chilena-del-cobre-cochilco

14 "Roadmap 2.0 of Chilean Mining Update and Consensus for a Fresh Look".

Alta Ley. 2019. https://corporacionaltaley.cl/wp-content/uploads/2020/03/AltaLey_ Roadmap2019_Ingles_V01_opt.pdf

15 "Alta Ley / ASDIT Designed a New Executive Board of Directors for its Application to the Institute of Clean Technologies". November 20, 2019. https:// corporacionaltaley.cl/en/asdit-designed-a-new-executive-board-of-directors-forits-application-to-the-institute-of-clean-technologies

16 "Technological institute for solar energy, low emission mining and advanced materials of lithium and other minerals". CORFO. 2019. https://www.oecd.org/ dev/Corfo-Session_7_Chilean-Clean_Technologies_Institute.pdf

17 "Technological institute for solar energy, low emission mining and advanced materials of lithium and other minerals". CORFO. 2019.

18 Cambero, Fabian. "Chile Launches Tender for Value-Added Lithium Projects". Reuters. March 25, 2019. https://www.reuters.com/article/ us-chile-lithium-sqm-idUSKCN1R621L

19 "Chile to Clean up Rules for Lithium Industry to Boost

Production". Reuters, June 11, 2019. https://www.reuters.com/article/ us-lithium-electric-chile-idUSKCN1TC1ZA

20 Jamasmie, Cecilia. "Chilean Legislators Reject Lithium Expropriation". MINING.COM. September 3, 2019. https://www.mining.com/

chilean-legislators-reject-lithium-expropriation

21 "Mineral Commodity Summaries 2020". U.S. Department of the Interior \& U.S Geological Survey. January 31, 2020. https://pubs.usgs.gov/periodicals/mcs2020/ mcs2020.pdf.

22 Plurinational State of Bolivia. Supreme Decree No. 29496 (2008). http://www. mineria.gob.bo/juridica/20080401-9-53-43.pdf

23 Mariette, Maëlle. "In Bolivia, the Lithium Sector up for Auction". Le Monde Diplomatique. January 2020. https://mondiplo.com/ en-bolivia-el-sector-del-litio-a-subasta. 
US\$ 1.3 billion; the deal was canceled in November 2019. ${ }^{24}$ YLB also entered into an agreement with a Chinese consortium to implement a US\$ 2.3 billion lithium project. ${ }^{25}$ In the aftermath of President Evo Morales's resignation in late 2019 and the ensuing political instability, the fate of these investments is uncertain ${ }^{26}$-but Bolivia's lithium dream lives on, based on hopes of increased demand. Juan Carlos Zuleta, YLB's chief until January 2020, intended to increase annual production of lithium from the current 400 metric tons to 50,000 metric tons in five years. ${ }^{27}$

\section{Great expectations are paired with great uncertainty}

With some countries already restructuring their legal frameworks and building infrastructure to optimize their projected profits, it is wise to evaluate the volatile foundation on which these forecasts rest, as to best prepare for the multitude of possible futures that lie ahead.

Building hopes on the anticipated boom in demand for the so-called critical minerals poses risks because nobody knows with certainty what the future of technology has in store-particularly affecting the uncertain demand for "minor metals with few and specific, mostly high-tech, applications." ${ }^{28}$ Today's technology-and its associated mining requirements-can become yesterday's news ${ }^{29}$ at a speed that far outpaces the adaptability of mines, threatening to leave these resource-intensive investments obsolete and economically stranded.

Technology development could take several pathways leading to reduced demand for some commodities.

\section{Increasing material performance}

First, continuously improving material performance has always been a main objective of material engineering. For example, while the lithium-ion battery is today's commercialized battery model of choice, it has its shortcomings, ${ }^{30}$ such as its high price point, fast aging, and need for protection circuitry. A substantial amount of $R \& D$ investment has been directed to accelerate battery technology towards cheaper, lighter, more energy dense and eco-friendly batteries.

Scientists at the California Institute of Technology and NASA's Jet Propulsion Laboratory have developed fluoride-ion chemistry, making it possible for engineers at the Honda Research Institute ${ }^{31}$ to develop a new battery that could replace traditional lithium-ion devices. ${ }^{32}$ Due to the light atomic weight of the element, fluoride-ion batteries (FIBs) are 10 times more energy dense than lithium ones, and could potentially power electric vehicles, airplanes, and cordless power tools.

And IBM Research has recently reported ${ }^{33}$ development on a new battery to power electric vehicles that is free of heavy metals such as cobalt and nickel and outperforms existing lithium-ion batteries given its lower cost, faster charging ability, higher energy and power density, higher energy efficiency, and lower flammability of electrolytes. Tesla, too, is developing new batteries that will rely on low cobalt or cobalt free innovations that will decrease internal stress and improve the ability to store energy for longer periods in both electric vehicles and home or commercial use. ${ }^{34}$

\footnotetext{
24 Carrie Hampel. "Decree Annulled on Bolivian-German Lithium Deal". Electrive.com. November 4, 2020. https://www.electrive.com/2019/11/04/ decree-annulled-on-bolivian-german-lithium-deal/;

Mining.com. "Germany Looks To Renew Scrapped Bolivian Lithium Deal". OilPrice.com. https://oilprice.com/Energy/Energy-General/Germany-Looks-ToRenew-Scrapped-Bolivian-Lithium-Deal.html

25 Ramos, Daniel. "Bolivia Picks Chinese Partner for \$2.3 Billion Lithium Projects". Reuters. February 6, 2019. https://www.reuters.com/article/ us-bolivia-lithium-china-idUSKCN1PV2F7

26 Vella, Heidi. "Bolivia: Will the Ousting of Morales Open Lithium to Foreign Investment?". Mining Technology | Mining News and Views Updated Daily. March 2, 2020. https://www.mining-technology.com/features/ bolivia-will-the-ousting-of-morales-open-lithium-to-foreign-investment/

27 Jourdan, Adam. "Exclusive: Bolivia's New Lithium Tsar Says Country Should Go It Alone". Reuters. January 15, 2020. https://www.reuters.com/article/ us-bolivia-lithium-exclusive-idUSKBN1ZE2DW

28 Renner, S., Wellmer, F. W.. "Volatility drivers on the metal market and exposure of producing countries". Mineral Economics. August 19, 2019. https://doi org/10.1007/s13563-019-00200-8

29 Tauber, Matthias, Jan Philipp Bender, and Matthias Tauber. "The New Technology Frontier in Mining". Boston Consulting Group. January 31, 2018. https://www.bcg.com/publications/2018/new-technology-frontier-mining.aspx
}

\footnotetext{
30 "Li-lon Battery Advantages / Disadvantages". electronicnotes. https://www.electronics-notes.com/articles/electronic_components/batterytechnology/li-ion-lithium-ion-advantages-disadvantages.php

31 Davis, Victoria K. et al. "Room-Temperature Cycling of Metal Fluoride Electrodes: Liquid Electrolytes for High-Energy Fluoride Ion Cells - RoomTemperature Cycling of Metal Fluoride Electrodes: Liquid Electrolytes for HighEnergy Fluoride Ion Cells - HRI-US". Science. December, 2018.

32 "New Battery Breakthrough Could Replace Lithium-Ion". ASSEMBLY. January 23, 2019. https://www.assemblymag.com/ articles/94724-new-battery-breakthrough-could-replace-lithium-ion

$33 \mathrm{Na}$, Young-hye. "Free of Heavy Metals, New Battery Design Could Alleviate Environmental Concerns". IBM Research Blog. December 18, 2019. https://www. $\mathrm{ibm} . \mathrm{com} / \mathrm{blogs} /$ research/2019/12/heavy-metal-free-battery/

34 Lienert, Paul, Norihiko Shirouzu. "Tesla's Secret Batteries Aim to Rework the Math for Electric Cars and the Grid". Reuters. May 14, 2020. https://www.reuters $\mathrm{com} /$ article/us-autos-tesla-batteries-exclusive-idUSKBN22Q1WC
} 
Similarly, a lot of R\&D is going into defining the photovoltaic cell technology that will optimize the solar-to-electrical energy conversion factors; ${ }^{35}$ and the National Renewable Energy Laboratory (U.S. Department of Energy) has counted four categories ${ }^{36}$ of competing photovoltaic cell technologies currently being developed worldwide, each with different material implications.

\section{Substituting due to high mineral prices}

A second pathway to mineral selection is good old fashion economics: When minerals become economically problematic, the industry adapts and minerals that were once deemed "critical" are replaced. The evolving role of cobalt within the energy sector over the past 80 years is a good example. In the 1940s, cobalt was thrust into significance when the aluminum-nickel-cobalt ( $\mathrm{AINiCo}$ ) magnet replaced electromagnets; ${ }^{37}$ and further secured its value in 1970 with the development of the even more energy dense samarium-cobalt magnet. ${ }^{38}$ However, due to the sudden increase in price of cobalt in the 1980 s $^{39}$ these magnets were superseded by neodymium iron boron magnets ${ }^{40}$ which remain the dominant magnet today. ${ }^{41}$

\section{Sulbstituting due to supply scares}

Third, in addition to high prices, inaccessibility of materials due to political leveraging (for example, the imposition of quotas, licenses, taxes, ${ }^{42}$ and export bans) and political conflicts can prompt investment in innovations that replace certain minerals with others.

This phenomenon was witnessed with respect to rare earth elements (REEs). ${ }^{43}$ These elements have physical and chemical properties that make them highly useful in various current technologies, including batteries,

\footnotetext{
35 Ayuk, E. T. et al. "Mineral Resource Governance in the 21st Century: Gearing extractive industries towards sustainable development". The International Resource Panel United Nations Environment Programme. 2019.

36 "Best Research-Cell Efficiency Chart". National Renewable Energy Laboratory https://www.nrel.gov/pv/cell-efficiency.html

37 Bell, Terence. "Cobalt Metal Characteristics, Production, Applications and More". ThoughtCo... August 13, 2019. https://www.thoughtco.com/ metal-profile-cobalt-2340131

38 Bell, Terence. "Cobalt Metal Characteristics, Production, Applications and More". ThoughtCo.. August 13, 2019

39 "Cobalt Price 2020 [Updated Daily]". Metalary. http://www.metalary.com/ cobalt-price/

40 "Resourcing Green Technologies through Smart Mineral Enterprise Development: A Case Analysis of Cobalt". Columbia Center on Sustainable Investment. http://ccsi.columbia.edu/files/2017/10/Resourcing-GreenTechnologies-through-SMED2.pdf

41 "The Role of Cobalt in NdFeB Permanent Magnets". Arnold Magnetic Technology. 2015. https://www.arnoldmagnetics.com/wp-content/ uploads/2017/10/TN_1502_rev_151214.pdf

42 Van Gosen, B.S. et al. "Rare-Earth Elements". U.S. Geological Survey. 2017 https://doi.org/10.3133/pp1802O

43 According to the International Union of Pure and Applied Chemistry, there are 17 REEs: cerium (Ce), dysprosium (Dy), erbium (Er), europium (Eu), gadolinium $(\mathrm{Gd})$, holmium ( $\mathrm{Ho}$ ), lanthanum (La), lutetium ( $\mathrm{Lu}$ ), neodymium ( $\mathrm{Nd})$, praseodymium $(\mathrm{Pr})$, promethium $(\mathrm{Pm})$, samarium $(\mathrm{Sm})$, terbium $(\mathrm{Tb})$, thulium $(\mathrm{Tm})$, and ytterbium (Yb) (the 15 lanthanides), plus scandium (Sc) and yttrium (Y)
}

magnets, lasers, and computers and other electronics. However, technological innovations leading to substitutions of minerals have allowed their criticality to be significantly reduced.

Following China's temporary ban on REE exports to Japan $^{44}$ in 2010, the Japanese automobile industry turned to R\&D geared toward mineral substitution. In response to the supply halt, Toyota greatly reduced ${ }^{45}$ their use of REEs terbium and dysprosium in their 2016 Prius, while Honda Motor Co eliminated the need entirely by co-developing the first hybrid car free of heavy REEs ${ }^{46}$ Looking forward, Toyota promises to eliminate ${ }^{47}$ terbium and dysprosium from future magnets, with plans to replace $50 \%$ of the expensive REE neodymium with the cheaper REEs lanthanum and cerium.

And the auto industry was not the only one to adapt their behaviors ${ }^{48}$ following the 2010 supply scare. Oil refineries temporarily abandoned lanthanum in their refining phase, and glassmakers forwent cerium in their polishing process while prices remained high.

\section{Reduce primary mineral extraction through recycling, reuse, and the circular economy}

A fourth area of uncertainty is the extent to which new mining will be replaced by reuse and recycling of materials. Rapidly evolving technology trends-motivated in part by circular economy policies, particularly in Europe-push for a progressive reduction in the need for the primary extraction of minerals. Regarding some minerals, these trends may eventually allow avoiding primary extraction altogether, with significant impacts on the traditional mining sector generally and, in particular, the hopes of mineral-rich developing countries.

Estimates of global recycling rates signal promising prospects for recycling some minerals that tend to be increasingly needed for the low-carbon energy transition. For example, a study by UN Environment Programme ${ }^{49}$ estimated end-of-life recycling rates-which measure the proportion of mineral products produced from scrap and other residues-at $70-90 \%$ for iron and steel, 43-53\% for

44 Bradsher, Keith. "Amid Tension, China Blocks Vital Exports to Japan". The New York Times, September 22, 2010. https://www.nytimes.com/2010/09/23/ business/global/23rare.html

45 Hsu, Jeremy. "Don't Panic about Rare Earth Elements". Scientific American May 31, 2019.

https://www.scientificamerican.com/article/dont-panic-about-rare-earth-elements/ 46 Shiraki, Maki, Tajitsu, Naomi. "Honda Co-Develops First Hybrid Car Motor Free of Heavy Rare Earth Metals." Reuters, July 12, 2016. https://www.reuters. com/article/us-honda-rareearths-idUSKCNOZSO6C

47 Bomgardner, Melody. "New Toyota Magnet Cuts Rare-Earth Use". Chemical and Engineering News. https://www.reuters.com/article/us-toyota-magnet/ new-toyota-magnet-cuts-dependence-on-key-rare-earth-metal-for-ev-motorsidUSKCN1G413F

48 Hsu, Jeremy. "Don't Panic about Rare Earth Elements". Scientific American 49 UNEP. "Recycling Rates of Metals - A Status Report". Resourcepanel.org. 2020. https://www.resourcepanel.org/reports/recycling-rates-metals 
copper, and $42-70 \%$ for aluminium. Steel already is the most recycled material ${ }^{50}$ globally, and recycling copper and aluminium is highly cost-effective, as they can be repeatedly recycled without performance loss and using $85 \%$ less energy than primary production. ${ }^{51}$

Prospects are admittedly not so promising for all minerals. Iron, copper, and aluminium are in the select group of 18 metals ${ }^{52}$ for which estimated end-of-life recycling rates are above $50 \%$. For many others, recycling rates are very low. For REEs, for example, recycling rates are at about $1 \% .^{53}$ As shown above, innovations allowing substitution of REEs have reduced their criticality to some extent. Even so, the inability to satisfy through recycling the still increasing demand for REEs and other minerals with low recycling rates, while manufacturers are still unable to do completely without them through substitution, pushes for greater primary extraction ${ }^{54}$ of these minerals.

At the same time, acknowledging the criticality of those minerals, their untapped recycling potential, ${ }^{55}$ and the potential social and environmental benefits ${ }^{56}$ and the avoided climate impacts ${ }^{57}$ of recycling over primary extraction has encouraged developed countries to increase investment in R\&D to improve recycling rates, as recommended by an OECD study. ${ }^{58}$ The European Union $^{59}$ has spent EUR 39 million on R\&D for REE recycling in the last decade; policy advocates have called for similar action in the United States. ${ }^{60}$

50 Steel Recycling Institute. "Steel Is the World's Most Recycled Material". https://www.steelsustainability.org/recycling

51 Schröder, Patrick. "Promoting a Just Transition to an Inclusive Circular Economy". April 1st, 2020. https://www.chathamhouse.org/sites/default/ files/2020-04-01-inclusive-circular-economy-schroder.pdf

52 "Mineral Production to Soar as Demand for Clean

Energy Increases". World Bank. May 11, 2020. https://

www.worldbank.org/en/news/press-release/2020/05/11/

mineral-production-to-soar-as-demand-for-clean-energy-increases

53 Jowitt, Simon M. et al. "Recycling of the Rare Earth Elements". Current

Opinion in Green and Sustainable Chemistry. October 1, 2018.

https://www.sciencedirect.com/science/article/pii/

S2452223617301256?via\%3Dihub

54 Schröder, Patrick. "Promoting a Just Transition to an Inclusive Circular Economy". April 1, 2020

55 The extent to which the potential is still untapped is unclear given the lack of up-to-date data on global recycling rates for a wide range of minerals. Most frequently cited global recycling rates-including in the World Bank's 2020 report and this paper-stem from a UN Environment Programme study of 2011 (footnote and this paper-stem from a UN Environment Programme study of
47 above). It may well be that recycling rates have improved since.

56 Parletta, Natalie. "Rare Earth Minerals Could Be Sourced Through Old Batteries, Smartphones, Wind Turbines". Forbes November 21, 2019. https:// www.forbes.com/sites/natalieparletta/2019/11/21/rare-earth-minerals-could-besourced-through-outdated-smart-phones-batteries-wind-turbines/

57 "The Circular Economy - a Powerful Force for Climate Mitigation". Material Economics. https://materialeconomics.com/publications/ the-circular-economy-a-powerful-force-for-climate-mitigation-1

58 Coulomb, R., et al, "Critical Minerals Today and in 2030: An Analysis for OECD Countries". OECD. September 28, 2015. https://doi.org/10.1787/5jrtknwm5hr5-en

59 Cole, Laura. "Europe Takes on China's Global Dominance of Rare Earth Metals".' www.euractiv.com, July 2, 2019. https://www.euractiv.com/section/ batteries/news/europe-takes-on-chinas-global-dominance-of-rare-earth-metals/

60 Ayala, Christine. "R\&D, Not Greenland, Can Solve Our Rare Earth Problem". The Hill. September 18, 2019. https://thehill.com/opinion/ energy-environment/462038-rd-not-greenland-can-solve-our-rare-earth-problem
In the same vein, the EU has also made its new Circular Economy Action Plan ${ }^{61}$ one the core components of the European Green Deal, focusing on various mineralintensive sectors, including electronics; information and communication technology (ICT); batteries; vehicles; and construction and buildings. In its action plan, the EU sets a best-efforts goal to double the use rate of circular material by 2030 . This is precisely within the timeframe that many new mines will come into production, potentially impacting demand and price expectations. Reaching this ambitious target would significantly affect the demand for primarily extracted materials from the developing world.

With global electronic waste (e-waste) projected to reach 120 million metric tons per year by $2050,{ }^{62}$ and less than $20 \%$ of it being formally recycled, the annual value of global e-waste is over US\$ 62.5 billion. ${ }^{63}$ For some scarce metals, such as gold, larger quantities are prevalent in e-waste than in the earth itself (100 times more gold is found in one tonne of e-waste than in one tonne of gold ore).

Given this unsustainable paradigm, members of the Platform for Accelerating the Circular Economy (PACE) and the United Nations (UN) E-Waste Coalition (including members of UN Environment, the World Economic Forum, the World Business Council for Sustainable Development, and the Global Environment Facility) have called for a global reboot ${ }^{64}$ of the electronics system; one that prioritizes recycling, reuse, urban mining, durable product design, and renting or leasing models over ownership of technology.

The growing momentum of recycling technologies can also be perceived in the update of the climate-smart mining report. While the 2017 World Bank report ${ }^{65}$ estimating the demand for minerals needed for the lowcarbon transition explicitly ignored recycling rates, ${ }^{66}$ the 2020 report $^{67}$ includes "additional analysis...on if and 61 "New Circular Economy Strategy - Environment - European Commission."
European Union. March 25, 2020. https://ec.europa.eu/environment/ circular-economy/

62 "A New Circular Vision for Electronics Time for a Global Reboot". Platform for Accelerating the Circular Economy. January 2019. http://www3.weforum.org/docs/ WEF_A_New_Circular_Vision_for_Electronics.pdf

63 "UN Report: Time to Seize Opportunity, Tackle Challenge of e-Waste". UNEP - UN Environment Programme. January 24, 2019 http://www.unenvironment.org/news-and-stories/press-release/ un-report-time-seize-opportunity-tackle-challenge-e-waste

64 "A New Circular Vision for Electronics Time for a Global Reboot". Platform for Accelerating the Circular Economy. January 2019. http://www3.weforum.org/docs/ WEF_A_New_Circular_Vision_for_Electronics.pdf

65 Arrobas, Daniele La Porta, et al. "The Growing Role of Minerals and Metals for a Low Carbon Future." The World Bank. June 30, 2017.

66 "This analysis calculates energy technologies' total demand for metals, but does not include a factor for what portion of that demand could be met by recycled metal." Arrobas, Daniele La Porta, et al. "The Growing Role of Minerals and Metals for a Low Carbon Future". The World Bank. June 30, 2017.

67 Kirsten Hund et al., "The Mineral Intensity of the Clean Energy

Transition". The World Bank, May 11, 2020. http://pubdocs.worldbank.org/ en/961711588875536384/Minerals-for-Climate-Action-The-Mineral-Intensity-ofthe-Clean-Energy-Transition.pdf 
how mineral recycling and reuse could potentially affect estimated mineral demand," focusing on five minerals only (aluminum, cobalt, copper, nickel, and lithium). Although concluding that strong demand for primary extraction would persist even if their recycling rates increased significantly, the 2020 report notes that "current recycling rates could reduce the required primary demand for minerals involved in the low-carbon transition" and that "future increases in recycling rates can play an important role in mitigating increases in demand for primary minerals." 68

We can reasonably assume that R\&D and technology developments resulting from stronger pushes for recycling, reuse, and the circular economy, will improve recycling rates and dampen the demand for primary extraction. For instance, Tesla is working on the recycling and recovery of nickel, cobalt and lithium to save on costs as well as on "second life" applications of electric vehicle batteries in grid storage systems. ${ }^{69}$

Finally, the circular economy also offers potential development opportunities ${ }^{70}$ for developing countries. For instance, the Nigerian government, along with the Global Environment Facility (GEF) and United Nations (UN) Environment Programme, kicked off a US\$ 15 million investment in a formal e-waste recycling industry ${ }^{71}$ in Nigeria. Excessive focus on expected mineral demand and investment can divert the attention of resource-rich countries' attention away from these development opportunities.

\section{Exploring increased reliance on agromining and biomining}

Fifth, research conducted since the 1990s has uncovered hundreds of hyperaccumulators-plant species that absorb and concentrate minerals at high levels. Their cultivation to extract minerals is called phytomining or agromining. ${ }^{72}$ Hyperaccumulating plants can be used as cleaners, to remove minerals from mine tailings and polluted soils for remediation purposes, or as miners, to literally farm for valuable elements in mineral-rich soils.

\footnotetext{
68 Kirsten Hund et al., "The Mineral Intensity of the Clean Energy Transition". The World Bank, May 11, 2020

69 Lienert, Paul, Norihiko Shirouzu. "Tesla's Secret Batteries Aim to Rework the Math for Electric Cars and the Grid". Reuters. May 14, 2020. https://www.reuters. com/article/us-autos-tesla-batteries-exclusive-idUSKBN22Q1WC

70 Wellesley, Laura. "How the Circular Economy Could Help Developing Countries Grow Sustainably". Ethical Corporation. http://www.ethicalcorp.com/ how-circular-economy-could-help-developing-countries-grow-sustainably

71 "UN Report: Time to Seize Opportunity, Tackle Challenge of e-Waste". UNEP UN Environment Programme. January 24, 2019

72 Ent, Antony Van der, et al. "Agromining: Farming for Metals: Extracting Unconventional Resources Using Plants". Springer International Publishing, 2018 https://www.springer.com/gp/book/9783319618982
}

Australia, Indonesia, Malaysia, and New Caledonia ${ }^{73}$ show great potential for the agromining of nickel, which has so far been the most successfully phytomined mineral, with relatively low production costs and high profitability. ${ }^{74}$ The potential of agromining extends to various other elements, ${ }^{75}$ including cadmium, cobalt, gold, platinum group elements, REEs, and zinc. ${ }^{76}$

While phytomining or agromining uses plants for mineral extraction, biomining (done in the two steps: bioleaching and biooxidation $)^{77}$ uses bacteria and other microorganisms to extract certain minerals from their ores-even from waste deposits in tailings. ${ }^{78}$ Cobalt, gold, nickel, silver, uranium, zinc, and notably copper ${ }^{79}$ are among minerals that can be extracted ${ }^{80}$ through biomining. Capital costs of biomining are about $50 \%{ }^{81}$ of those of conventional smelting and refining operations, and its competitiveness tends to increase as energy costs decrease.

For reasons of scale, agromining and biomining are unlikely to obviate the need for traditional mining. Even so, as these technologies are further developed and become more economical, they will tend to play increasingly important roles in complementing the supply of critical minerals with lower impacts on the local environment and on the global climate, creating more uncertainty on mining demand trends in resource-rich developing countries.

\section{Adopting a herd mentality poses significant risks}

The mining industry has always been a cyclical one, and investment patterns have generally followed the cycle. When demand is growing and prices increase, investments in the top minerals rise. At a certain point,

\footnotetext{
73 Morse, lan. "Down on the Farm that Harvests Metal from Plants". The New York Times. February 26, 2020. https://www.nytimes.com/2020/02/26/science/ metal-plants-farm.html

74 Clifford, Martin et. al. "Extracting Innovations: Mining, Energy, and Technological Change in the Digital Age". CRC Press. May 8, 2018. https://www.routledge.com/Extracting-Innovations-MiningEnergy-and-Technological-Change-in-the/Clifford-Perrons-Ali-Grice/p/ book/9781138040823

75 Ent, Antony Van der, et al. "Agromining: Farming for Metals: Extracting Unconventional Resources Using Plants". Springer International Publishing, 2018. https://www.springer.com/gp/book/9783319618982

76 Adams, Reuben. "Petal to the Metal: How 'Phytomining' Could Transform Mine Waste into Big \$\$". Stockhead. July 17, 2019. https://stockhead.com.au/resources/ petal-to-the-metal-how-phytomining-could-transform-mine-waste-into-big/

77 Mahajan, Surabhi, et al. "Bioleaching and Biomining". In Principles and Applications of Environmental Biotechnology for a Sustainable Future. October 15, 2016. https://doi.org/10.1007/978-981-10-1866-4_13

78 Falagán, Carmen et al. "New Approaches for Extracting and Recovering Metals from Mine Tailings". Minerals Engineering, Biohydrometallurgy. May 15, 2017. https://doi.org/10.1016/j.mineng.2016.10.008

79 Dresher, William. "Innovations in Copper: Mining \& Extraction: Producing Copper Nature's Way: Bioleaching". May 2014. https://www.copper.org/ publications/newsletters/innovations/2004/05/producing_copper_natures_way_ bioleaching.html

80 "Bioleaching Definition \& Process". AngloAmerican. https://www. angloamerican.com/futuresmart/our-industry/mining-explained/ mining-terms-explained-a-to-z/bioleaching-definition-and-process

81 Dresher, William. "Innovations in Copper: Mining \& Extraction: Producing Copper Nature's Way: Bioleaching". May 2014.
} 
almost inevitably, too much capacity to produce comes online, and this reverses the supply and demand equation, causing prices to drop again until demand rises back up. This pattern is not unique to mining; we have seen it in other commodities, including, most recently, in the oil and gas sector.

Too many countries and companies adopting a "herd" mentality and rushing to produce the minerals needed for today's energy technology constitutes serious risks of over-supply.

\section{Risks of overproduction}

A flooded market due to promotion by world development agencies and banks could incite a market value crash. The classic example of this was seen in the coffee sector $^{82}$ when Vietnam, boosted by government assistance, ${ }^{83}$ ramped up their production $1100 \%$ in the 1990 s $^{84}$ wreaking havoc on the price of coffee globally in the process.

Closer to home for our purposes, from 2016 to early 2018 , cobalt experienced an unprecedented price surge ${ }^{85}$ as a result of optimistic forecasts for the EV sector which spurred a "cobalt rush." By March 2018, the supply surplus brought about a precipitous collapse ${ }^{86}$ with cobalt losing around $70 \%$ of its value.

\section{Resource curse and "presource" curse risks}

Even though a discovery of resources or a boom in resource-related industries should lead to increased output and economic growth, it is a well-recognized fact that countries rich in non-renewable resources tend to experience slower economic growth, more social issues, and worse development outcomes than less endowed countries-a paradox known as the resource curse. ${ }^{87}$

In addition to the threat of the resource curse, overly zealous expectations can drive suboptimal behaviors, resulting in resource-rich countries experiencing slower economic growth before any minerals are even extracted. This phenomenon of economic underperformance following

82 Sachs, Jeffrey. "Ensuring Economic Viability and Sustainability of Coffee Production". Columbia Center on Sustainable Investment. October 2019. http:// ccsi.columbia.edu/files/2020/02/Ensuring-Economic-Viability-and-Sustainability-ofCoffee-Production.pdf

83 "Country Coffee Profile: Vietnam". International Coffee Organization. March 25-29, 2019.

http://www.ico.org/documents/cy2018-19/icc-124-9e-profile-vietnam.pdf

84 Craves, Julie. "The Coffee Crisis - Coffee \& Conservation". Coffee and Conservation. February 8, 2006. https://www.coffeehabitat.com/2006/02/ the_coffee_cris/

85 "Congo Declares Cobalt 'Strategic', Nearly Tripling Royalty Rate". Reuters. December 3, 2018

86 "Why Have Cobalt Prices Crashed". International Banker. July 31, 2019. https:// internationalbanker.com/brokerage/why-have-cobalt-prices-crashed/

87 "The Resource Curse - The Political and Economic Challenges of Natural

Resource Wealth". National Resource Governance Institute. April 27, 2015. https:// resourcegovernance.org/analysis-tools/publications/primer-resource-curse over-optimism among governments and international institutions is known as the presourse curse. ${ }^{88}$ In this case, it is the promise of resource abundance, rather than the abundance itself, that leads to an economic downturn. ${ }^{89}$ And just as it has been observed in new oil producer countries, so too does it threaten to curtail the economic development of emerging mineral-rich countries.

Elevated expectations can drive harmful behaviors. ${ }^{90}$ For example, the projections may first influence the media and civil society to put pressure on their government to engage in imprudent and risky overspending or overborrowing. ${ }^{91}$ Second, lenders and rating agencies may be swayed as well, resulting in artificially low borrowing costs, leading to further overborrowing. ${ }^{92}$ And third, given the complexity, inherent geological risk, and high upfront cost of mining projects, some of these projects might not come to fruition, leaving countries without the profits they anticipated. The presource curse suggests an over-reliance by governments on one path to an economic future, instead of planning increasingly diversified economic growth.

Because of these factors, countries can see their public spending programs compromised and debt sustainability worsen, leaving them engaged in public development programs and debt programs that they are no longer able to finance.

\section{A word of caution for resource-rich countries: How to hedge against the risks of inflated expectations?}

Reliance on the expectations for green energy materials should not replace careful planning, assessment of specific opportunities, and allocation of mining risks, to ensure against over-production. While the World Bank and other organizations are rightly promoting "climatesmart" mining ${ }^{93}$ to help resource-rich countries maximize their returns, governments should address the risks that not all green energy related mining will, in itself, be "smart mining," as demonstrated above.

88 Mihalyi, David, Cust, Jim. "What Is the Presource Curse?". Natural Resource Governance Institute. November 28, 2017. https://resourcegovernance.org/blog/ what-presource-curse

89 Mihalyi, David, Cust, Jim. "The Presource Curse - Finance \& Development December 2017". International Monetary Fund. December 2017. https://www.imf. org/external/pubs/ft/fandd/2017/12/cust.htm

90 Mihalyi, David, Cust, Jim. "The Presource Curse - Finance \& Development, December 2017". International Monetary Fund. December 2017.

91 Mihalyi, David, Cust, Jim. "What Is the Presource Curse?". Natural Resource Governance Institute. November 28, 2017

92 Mihalyi, David, Cust, Jim. "The Presource Curse - Finance \& Development December 2017". International Monetary Fund. December 2017.

93 "Climate-Smart Mining: Minerals for Climate Action". World Bank. http:// pubdocs.worldbank.org/en/961711588875536384/Minerals-for-Climate-ActionThe-Mineral-Intensity-of-the-Clean-Energy-Transition.pdf 
Governments (and the private sector) can take a number of steps to maximize the value of climate-smart mining and minimize its risks. Among these steps are:

\section{Recognizing that not all minerals will be the same: there is a need to analyze each proposed project separately}

Whether a potential project related to green energy commodities is first developed by the government or first proposed by the private sector, it is important to carefully analyze the project. Some key factors to take into account are set out below. For here, the key point is that each potential project has to be analyzed in detail, without assuming that globalized forecasts for green energy technology will guarantee positive results from the project. Globalized forecasts have to be individualized to each project to be validated in order to make an informed decision on its likely success, commercial viability, and net value to the government in terms of revenues versus costs.

\section{Considering several factors in evaluating each project}

a. Understanding global levels of investment in any given commodity: The value of any given project will be a function of future supply and demand when the mine production begins. This could be several years from when a mine plan is being developed. So it is very important to understand the global investment market for a commodity. Contrary to herd thinking, if everybody is doing it, that may be a very good reason not to do the same thing. Over-investment in a commodity can, as discussed above, kill the market price for all producers and make the cost of production the critical factor in a mine's success or failure. Understanding different market scenarios against the proposed cost of production is critical.

b. Understanding competing pathways of industry for that commodity and risks of technology change associated with it: Is the proposed mine dependent on one technology for its success so that markets for it are limited, or are there multiple markets and uses for a product on the market? The more diversified the utility of the commodity, the better the chance for a product to find a market if one use becomes outdated for whatever reason.

c. Building scenario and sensitivity analysis capacity: It is important for governments to understand how to build and model different scenarios for future demand and prices, and what this means for the economics of a proposed mine. This effort takes both commodity specific expertise and modelling expertise, which may not always be available inhouse. Even so, these are critical inputs in assessing the viability of a proposed mine.

\section{Understanding economic spillover effects from new technology in mining}

a. When assessing the potential value of a proposed mine, it is important to carefully assess the related economic spillovers: local employment, ${ }^{94}$ local inputs of goods and services, ${ }^{95}$ shared-use of infrastructure, ${ }^{96}$ social development benefits ${ }^{97}$ of a project, etc. These factors are part of the equation for making an informed decision, but it is difficult to assess whether they may make an otherwise marginal business proposition worth proceeding with. Most importantly, however, when these factors are being considered it must be in the context of the technology and design being put forward by the project proponent. Many new mining technologies ${ }^{98}$ are coming on line now that provide few opportunities for large-scale employment or local purchasing. ${ }^{99}$ So these issues must be tied to actual planning and not theoretical assumptions of economic spillovers.

b. Does the mining project provide an anchor for economic diversification? Can some or all of the mine's proposed production be used in-country or within the neighboring countries to promote more local and regional development? Can the mines collaborate with local technology institutes in transferring skills ${ }^{100}$ for the other sectors of the economy or to enable job creation even in the context of automation? These types of economic spillovers can be critical to diversify economies.

\footnotetext{
94 "Employment from Mining and Investments in Land for Agriculture". Columbia Center on Sustainable Investment. http://ccsi.columbia.edu/work/ projects/employment-from-mining-and-investments-in-land-for-agriculture

95 "Intergovernmental Forum on Mining, Minerals, Metals and Sustainable Development (IGF)". International Institute for Sustainable Development. https:// www.iisd.org/library/igf-guidance-governments-local-content-policies

96 "Leveraging Mining-Related Infrastructure Investments for

Development (Rails, Port, Power, Water and ICT)". Columbia Center on Sustainable Investment. http://ccsi.columbia.edu/work/projects/ leveraging-infrastructure-investments-for-development

97 "Community Development Requirements: Laws, Best Practices, and Community Development Agreements Database". Columbia Center on Sustainable Investment. http://ccsi.columbia.edu/work/projects/ community-development-agreements-frameworks-and-tools
}

98 "Mining a Mirage: Reassessing the Shared-Value Paradigm in Light of the Technological Advances in the Mining Sector". Columbia Center on Sustainable Investment. http://ccsi.columbia.edu/2016/09/01/mining-a-mirage-reassessingthe-shared-value-paradigm-in-light-of-the-technological-advances-in-the-miningsector

99 "The Mine of the Future". Columbia Center on Sustainable Investment September 2016. http://ccsi.columbia.edu/work/projects/the-mine-of-the-future 100 "South Africa: Horizontal linkages - Building expertise by overcoming country-specific constraints (Case Study)". Intergovernmental Forum on

Mining, Minerals, Metals and Sustainable Development (IGF). IGF Guidance for Governments: Leveraging Local Content Decisions for Sustainable Development. Winnipeg: IISD. 2018. https://www.iisd.org/sites/default/files/publications/casestudy-south-africa-horizontal-linkages.pdf 


\section{Understanding the potential fiscal benefits (revenues) from a proposed mine}

a. There are a number of inter-related issues: What are the expected tax and royalty revenues from a proposed mine? Is the private sector partner heavily invested in aggressive tax planning and treatyshopping enabling transfer pricing, profit shifting, and minimization of withholding taxes on dividends? Is the beneficial owner known and directly implicated in the project development? Does the government have a good fiscal model for the proposed project, without relying only on the project proponent?

b. Governments must carefully consider the need for any tax or other incentives. ${ }^{101}$ These incentives can end up costing the government more than it receives over the lifetime of a project. This is especially important when it comes to tax holidays, which can leave a government with far less revenue than anticipated as companies adjust the rates of production to maximize the value of such holidays. ${ }^{102}$

\section{Thinking outside the box}

New challenges present opportunities for rethinking old approaches to mining. COVID-19 might have provided momentum for it as the global halt in mining production ${ }^{103}$ has brought to light the importance of securing a steady mineral supply chain. ${ }^{104}$ For example, are there relationships that can be built with corporate consumers directly to stabilize future markets for production up front, through, for instance, long-term contracts and strategic partnerships? Can governments remain the owners of the mine, or jointly own a mine with the end-user of the product instead of the mining company? These might be beneficial when the commodity is focused on one or two types of end-users who also have a need for secure supply lines. Finally, can new minerals be found in urban e-waste or existing tailings instead of through primary extraction, thereby developing the basis of a circular economy?

The options above are some of the ones available to governments and the private sector to improve the opportunities for success of a proposed mine. Some or all of these may be relevant to assess a potential future project.

Our key point remains clear regardless of these variables: globalized forecasts for climate-smart mining do not guarantee the success of any individual proposed project. There is not a pot of gold waiting to be picked up at the end of every mining rainbow. Governments should take the responsibility to assess each project on its own merits and plan accordingly. Cautious and specific assessment and planning are the best guarantees of a successful project.

\section{Acknowledgements}

The authors are grateful to Sepp Duncan Panzer for his invaluable research and editing support; and to Michael Morgan for his edits and exceptional job formatting this paper. 


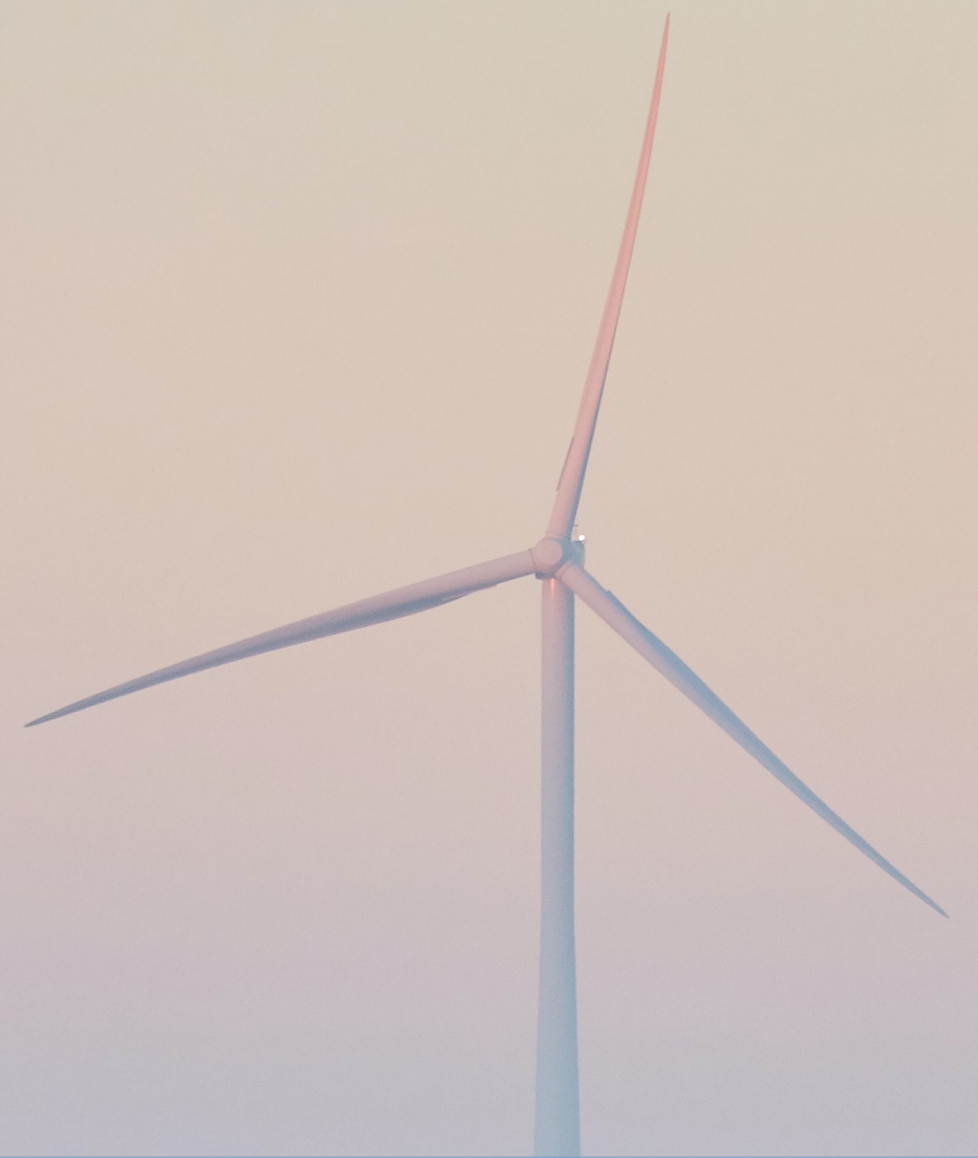

ccsi.columbia.edu

Columbia Center on

Sustainable Investment

Jerome Greene Hall

435 West 116th Street

New York, NY 10027

Phone: +1 (212) 854-1830

Email: ccsi@law.columbia.edu 